Trans/Form/Ação, São Paulo,

12: 1-22, 1989.

\title{
A COMÉdiA DESCLASSIFICADA DE MARTINS PENA
}

Iná Camargo COSTA*

RESUMO: Após indicar o caráter ideológico de conceitos básicos habitualmente mobilizados em análises da literatura dramática, este estudo tenta mostrar que é possível enxergar mais longe quando nos livramos dos limites por eles impostos. Detectada a fundamentação classista da história do teatro no Brasil, a luta ideológica aparece como um refletor capaz de iluminar aspectos normalmente obscurecidos das comédias de Martins Pena.

UNITERMOS: Teatro moderno; drama; comédia de costumes; comédia dramática; alta comédia; farsa; literatura dramática; teatro épico.

\section{PRÓlOGO}

A confusão conceitual existente no Brasil a respeito do teatro moderno já podia ser observada no século passado, embora seu conteúdo nem sempre seja o mesmo. Ela aparece, por exemplo, no aplauso de José de Alencar ao teatro Ginásio Dramático, dirigido pelo francês Emile Doux. Conforme a avaliação do nosso romancista e também dramaturgo, o Ginásio teria introduzido no Rio de Janeiro a "verdadeira" escola moderna

* Departamento de Línguas Orientais - Faculdade de Filosofia, Letras e Ciências Humanas USP - 05508 - São Paulo - SP. 
(Cf. 1, p. 31-7). O representante da tal escola moderna era nada menos que Alexandre Dumas Filho, embora, para Alencar, Molière, Beaumarchais e outros também já fizessem "teatro moderno".

Fazendo de maneira oblíqua uma avaliação do que teria sido o projeto fluminense de fazer teatro de acordo com a entāo moderna escola parisiense ou, para dar nome aos bois, produzir aqui dramas como os de Dumas Filho, que faziam grande sucesso de público, Vilma Arêas descobre o grande mérito de Martins Pena: o abandono desse projeto em favor da comédia de costumes. Nas palavras de Vilma Arêas, "voltando-se para o cotidiano brasileiro, Martins Pena deixa de ser 'moderno' e se salva para o futuro" (4, p. 110.). É ainda a ela que devemos a demonstração da vantagem estética dessa opção pela comédia de costumes no caso de Martins Pena. Para realizá-la, o comediógrafo voltou-se para o cotidiano das nossas classes populares, uma vez que o material disponivel ("grande" sociedade e seus hábitos culturais) tinha características muito pouco propícias para a elaboração de dramas. Poderíamos acrescentar que havia um abismo entre as exigências formais do drama (dados os seus pressupostos sociais) e a matéria social com que os candidatos a dramaturgo podiam trabalhar. Por isso o reincidente fracasso (ao menos de crítica) de quase todas as tentativas de criação do nosso "teatro nacional" em chave dramática, quando esse mesmo teatro ia sendo feito em chave cômica. Daí a espécie de mal-estar com que a intelectualidade contemporânea e mesmo póstera sempre viu o sucesso de público de certa comédia, sempre relegada a um grau inferior na hierarquia da arte dramática. É com uma espécie de complacência que José de Alencar, por exemplo, "aplaude" Martins Pena, um dos fundadores do "teatro nacional", o mesmo que, na opinião de Alencar, ainda estava por ser criado: "Dois escritores (...) começaram entre nós a escrever para o teatro; mas a época em que compuseram as suas obras devia influir sobre a sua escola. O primeiro, Pena, muito conhecido pelas suas farsas graciosas, pintava até certo ponto os costumes brasileiros; mas pintava-os sem criticar, visava antes ao efeito moral; as suas obras são antes uma sátira dialogada, do que uma comédia. Entretanto Pena tinha esse talento de observação, e essa linguagem chistosa, que primam na comédia; mas o desejo de aplausos fáceis influiu no seu espírito, e o escritor sacrificou talvez suas idéias ao gosto pouco apurado da época. Se tivesse vivido mais alguns anos, estou convencido de que, saciado dos seus triunfos, empreenderia uma obra mais elevada, e introduziria talvez no Brasil a escola de Molière e Beaumarchais, a mais perfeita naquele tempo" (2, p. 44).

Não é outro, por sinal, o espírito com que Machado de Assis se referirá à obra do comediógrafo: "Não falo do Pena, talento sincero e original, a quem só faltou viver mais para aperfeiçoar-se e empreender obras de maior vulto" $(9$, p. 145). E quanto à permanência da idéia de que, se não o "teatro nacional", pelo menos a nossa literatura dramática ainda esperava por seu iniciador, veja-se a seguinte avaliação de José Veríssimo: "Sou dos que pensam que temos obras dramáticas, que no interesse de uma classificação de história literária poderíamos mesmo falar num "teatro brasileiro" sem dar à expressão senão um valor bibliográfico, mas que não seria verdadeiro falar de uma "literatura dramática" brasileira. E há muitas causas a impedir-nos de ter uma literatura 
dramática, sendo uma das principais, além das puramente sociais, que o drama vive da idéia e da criação e até hoje, salvo uma ou outra exceção que confirma a regra, a nossa literatura de ficção em prosa ou verso é uma literatura puramente emotiva ou descritiva" (15, p. 120).

Diga-se de passagem que o próprio Martins Pena partilhava dessa espécie de preconceito contra a comédia, como já mostraram Jaime Rodrigues (13) e Vilma Arêas (4). Mas, antes que se estabeleça um sério mal-entendido, é preciso esclarecer um pouco esse preconceito e restringir o seu alcance. Como o próprio texto de Alencar acima citado indica, há, ou pelo menos havia, um tipo de comédia que todos apreciavam. Trata-se da chamada "alta comédia" ou, para usar o conceito mais preciso de Lukács, da comédia dramática (8. p. 123) - o verdadeiro ideal de nossa intelectualidade oitocentista que desejava introduzir no Brasil um importante melhoramento da vida moderna corrente na Europa: o teatro burguês em suas duas vertentes, ou seja, o drama - ideal máximo com o qual todos sem exceção sonharam - e a sua versão humorística, por assim dizer, mais leve, que é a "alta comédia", da qual Molière teria sido um dos maiores expoentes, e cujo legítimo sucessor, na opinião de Alencar, era nada menos que Dumas Filho (não por acaso, o seu próprio modelo).

Não havendo neste momento a necessidade de nos demorarmos sobre esse aspecto dos anseios de nossa melhor intelectualidade, para a demonstração de que o ideal de todos, em se tratando de comédia, voltava-se para a comédia dramática, basta reproduzir algumas observaçð̄es de Machado de Assis em tempos de crítico teatral. Num longo elogio a José de Alencar, trata de compará-lo com Martins Pena, dando vantagem ao primeiro, e de mostrar que a peça Rio de Janeiro, verso e reverso documenta uma fase de transição em sua dramaturgia, exatamente no rumo da alta comédia: "Verso e reverso deveu o bom acolhimento que teve, não só aos seus merecimentos, senão também à novidade da forma. Até então a comédia brasileira não procurava os modelos mais estimados; as obras do finado Pena, cheias de talento e boa veia cômica, prendiam-se intimamente às tradiçðes da farsa portuguesa, o que não é desmerecê-las, mas defini-las; se o autor do Noviço vivesse, o seu talento, que era dos mais auspiciosos, teria acompanhado o tempo, e consorciaria os progressos da arte modema às liçōes de arte clássica (...) Verso e reverso não era ainda a alta comédia, mas era a sociedade polida que entrava no teatro, pela mão de um homem que reunia em si a fidalguia do talento e a fina cortesia do salão". E continua Machado de Assis: "A alta comédia apareceu logo depois, com $O$ demônio familiar" (10. p. 211).

Este passo da crítica machadiana, além de documentar em termos literais o que dizíamos, tem a vantagem de indicar o conteúdo social, mais precisamente, de classe do ideal dramático (no Brasil como na Europa, diga-se). O problema do teatro "nacional" (no caso, da comédia "do Pena") não estava nas suas raízes, ou nas raízes do seu modelo, e sim no material selecionado pelo dramaturgo: enquanto Martins Pena, na linguagem da comédia popular, punha no palco estratos das classes subalternas, inclusive escravos, todos lançados numa furiosa luta pela sobrevivência - sempre de muito mau gosto para 
os coraçð̄es "bem formados" -, José de Alencar, com os "progressos da arte moderna", desconsiderava os usos e costumes "dessa gente" em favor dos problemas (mais "família") da "sociedade polida" e, ainda por cima, com conhecimento da "fina cortesia de salão". Em poucas palavras, tratava-se de "selecionar melhor", com um pouco mais de "bom gosto", fórmulas, temas, assuntos, etc., para dar ao teatro feito por aqui a mesma "polidez" observada por Alencar, ao correr da pena, nas atitudes da "gente bem" nos passeios, festas, compras, namoros, maneiras de vestir, de falar, etc. Enfim, devolver a "chusma" a seu devido lugar - a saber, à platéia, de onde poderia aprender "boas maneiras" e "delicadezas de sentimentos" com os exemplares do drama e da comédia dramática que já vinham anunciados na própria obra de José de Alencar. Esta é uma faceta do processo ideológico da modemização conservadora em andamento naqueles tempos, muito bem insinuada por Flávio Aguiar quando identifica o intuito "moralizador" da dramaturgia alencariana: "Alencar explica o nascimento da sua veia de dramaturgo em termos moralistas (...): o estopim foi o fato de ver senhoras rirem diante de uma farsa que, segundo ele, nāo primava pela moralidade e pela decência da linguagem. Daí nasceulhe o impulso de fazer rir sem fazer corar; e deste, nasceu sua primeira peça (...) Em termos de representação, portanto, estamos diante do mesmo impulso que levara Alencar a elogiar o Ginásio no Ao correr da pena: ele preza a circunspecção, a elegância na representação, tudo longe do vulgar" (1, p. 38).

A título de hipótese provisória, podemos dizer que nas décadas de 50 e 60 do século passado a dramaturgia brasileira, que mal começara a existir na década anterior (é de 1838 a sua peça inaugural, $O$ poeta $e$ a Inquisição, drama de Gonçalves de Magalhães), já enfrenta em completa desigualdade de condições a luta que na Europa durou cerca de dois séculos: a imposição do princípio burguês do drama ao preço da expulsão, condenação, excomunhão, perseguição, etc., etc., das "formas populares" do teatro, que só começaram a despertar novo interesse, não por acaso, no início deste século (como se sabe, Brecht, Maiakóvski e outros não reivindicavam nenhuma originalidade para o seu teatro; ao contrário, apontavam suas fontes no teatro medieval, no oriental e nas várias formas de diversão popular, inclusive os espetáculos de cabaré, circo, etc.). Um problema que só podemos indicar, até porque o material necessário à pesquisa simplesmente não é disponível, é o resultado real (artístico) de todas as tentativas de imposição do princípio burguês à prática brasileira. Se, por um lado, a simples identificação desse problema pð̃e em xeque a totalidade das avaliaçð̄es de nossa dramaturgia, por outro, a reconsideração dos "fracassos" das tentativas de se criar o "drama brasileiro", ou mesmo de "sucessos" como Os mineiros da desgraça de Quintino Bocaiúva, para dar apenas um exemplo, passa necessariamente por um trabalho que sequer pode ser pensado em termos de esforço individual. E o elogio que Machado de Assis faz ao amigo a propósito do grande sucesso da peça (10, p. 162-9) está longe de poder ser reduzido a mera peça propagandística.

Uma conseqüência da adoção do princípio dramático por nossa intelectualidade - cujo resultado mais dramático (ou cômico?) tem sido a cegueira para o que há aqui - pode ser sentida, ainda hoje, até mesmo nos melhores estudos sobre a dramaturgia no Brasil. O próprio descaso com que se tem tratado da preservação ou da publicação de textos é 
expressão disso. Nossa dramaturgia nunca passou de "prima pobre" no conjunto da literatura e dos estudos literários principalmente porque o tearro que sempre se fez no Brasil insistia em não corresponder àquele ideal dito europeu, mas simplesmente burguês, de circunspecção e elegância, permanecendo sempre às voltas com tipos e temas "vulgares" e de "mau gosto" (pelo menos é o que sugerem as avaliaçð̃es correntes).

Mesmo partilhando, com algumas restriçðes, desse preconceito ou opção ideológica, o que dá no mesmo, um trabalho como o de Vilma Arêas já aponta a possibilidade e sobretudo a necessidade de superá-lo. Este mérito da autora é claramente indicado pelo prof. Décio de Almeida Prado, o nosso melhor crítico teatral que, entretanto, também não está imune a esse preconceito, como se pode observar no passo a seguir: "Que propð̄e a autora para refutar José Veríssimo? Primeiro, que o teatro é senhor de seu espaço próprio, de sua autonomia, não se deixando reduzir exclusivamente a termos literários. Se Martins Pena foi um bom escritor de teatro, um escritor viável cenicamente, ao mesmo tempo que voltado para o que via ao seu redor, isso já nos deve contentar e até surpreender, em se tratando de um pioneiro em sentido quase absoluto. Segundo, que não há gêneros inferiores, nem mesmo os chamados primitivos, verdade que descobrimos com o modernismo". E, mais adiante, continua o nosso autor: "A autora revela que as farsas de Martins Pena, em vez de representarem o degrau mais baixo da escala teatral brasileira, assentavam-se sobre fundamentos que custamos a enxergar exatamente porque escapavam por completo ao âmbito literário. Constituíam-se elas não somente de entremezes portugueses - o que já se sabia - mas ainda de espetáculos de feira, de teatrinhos mecanizados, de circos de cavalinhos, de números de rua extremamente engenhosos. $\mathrm{O}$ livro contempla todo esse subteatro, não diremos com olhos entemecidos, que a tanto não consente a objetividade acadêmica, mas com evidente simpatia, nascida de uma concep̧̧ão menos aristocrática de arte que começa a se esboçar no Brasil" (4, Prefácio).

Duas ou três informaçðes desse prefácio reclamam algum comentário. A primeira diz respeito à sugestão de excluir o teatro do âmbito literário, idéia que agrada tanto a um certo tipo de teóricos da literatura quanto a uma forte corrente (hoje eventualmente hegemônica) de teóricos das artes cênicas. Não deixa de ser uma boa solução conciliatória, na medida em que, por ela, é possível preservar tanto as teorias teatrais apoiadas nas fórmulas do playwrighting quanto as "conquistas" formais e técnicas do teatro moderno sem precisar submetê-las a qualquer tipo de exame crítico. Posto o teatro fora do âmbito literário, o texto torna-se apenas um elemento entre outros de um espetáculo, ficando a sua análise livre para limitar-se a uma simples enumeração dos seus elementos, na medida em que, como se costuma dizer, só interessa o espetáculo como um todo, a partir de sua realização; sozinho o texto não quer dizer nada.

Ora, essa vertente teórica é bem mais antiga do que fazem supor seus mais recentes adeptos. O próprio José Veríssimo já a encampava, tendo porém o cuidado de indicar sua matriz francesa, como se pode observar neste passo: "Assentemos primeiramente esta noção que me parece incontestável: Martins Pena é um escritor de teatro e somente isso; quero dizer que as suas capacidades não vão além do necessário para fazer uma peça 
representável e que ele, sem nenhuma distinção especial de talento, possui apenas essas capacidades. Uma tal aptidão não indica por forma alguma qualidades artísticas e literárias, nem basta para dar ao que a possui foros de escritor e um lugar na literatura. São que farte os exemplos citáveis em abono ao meu asserto, e para lhe demonstrar a exatidão bastaria recordar não só o nosso próprio meio, mas os povos que como nós possuem autores dramáticos sem terem todavia uma literatura dramática. Os franceses distinguem naturalmente as duas coisas com a expressão 'escritor de teatro', que eles têm por centenas, quando os que realmente se incorporam à sua literatura são pouquíssimos. O teatro é uma arte especial, com a sua técnica e a sua estética próprias, oriundas das mesmas exigências cênicas e da natureza peculiar do seu destino e do modo por que o realiza. Vive talvez do seu próprio fundo como uma arte independente, e a sua história acidentalmente coincide com a da literatura. Esta observação, que é do citado crítico francês, e me parece justa, explicaria porque a existência de escritores de teatro, e do que se chama coletivamente 'teatro', não implicaria a existência de uma literatura dramática (...)" (15, p. 120). Como se pode ver, se Vilma Arêas discorda de José Veríssimo, não é neste ponto.

A segunda informação diz respeito àquela "verdade" que teríamos descoberto com o modernismo - a de que não há gêneros inferiores, nem mesmo os chamados primitivos. Um estudo sobre os aspectos políticos da história do teatro moderno pode mostrar resultados um pouco diferentes dessa espécie de "constituição estética liberal", segundo a qual "todos os gêneros seriam iguais perante a lei". Nessa história encontra-se antes um longo processo de luta, que não dispensou nem mesmo a intervenção policial, para não falar em massacre político, no qual um princípio historicamente superior ao do drama conseguiu impor-se durante um curto período, mas depois, em decorrência das vitórias burguesas, com suas novas alianças consolidadas no segundo pós-guerra, foi obrigado a recuar para sobreviver degradado até hoje. É assim que continua a haver uma hierarquia das formas teatrais. $O$ que mudou foi o pressuposto político da valorização ou desvalorização desta ou daquela forma nessa espécie de supermercado de formas e gêneros em ampla liquidação que determina a produção cultural contemporânea. A suspensão do juízo, por sua vez, está intimamente vinculada à estratégia aparentemente conciliatória apontada acima, que agora, em tempos de capitalismo tardio, expð̋e com muita nitidez o seu caráter de hegemonia de classe, para falar como Gramsci. O próprio professor Décio de Almeida Prado mantém implícita uma hierarquia das formas teatrais ao chamar de subteatro os espetáculos populares de que se utilizaram Martins Pena e dramaturgos modernos como Brecht e Maiakóvski, para lembrar apenas nomes bem conhecidos.

Finalmente, ao referir-se à simpatia pelas formas de teatro popular, nascida de uma concepção menos aristocrática de arte, nosso professor dá uma pista da fundamentação classista que teve (ou tem) esse preconceito que marcou decisivamente a história desfocada do teatro no Brasil e que está por trás de todas as profissōes de fé nacionalistas em favor da criação do "teatro nacional", quando esse mesmo teatro ia sendo feito nas feiras, praças, nos circos e teatros que a intelectualidade evitava registrar em nome dos duvidosos critérios de bom gosto, elegância e dignidade alardeados por nossas classes 
dominantes. Pois bem: é essa luta ideológica o refletor com que pretendemos iluminar alguns aspectos normalmente obscurecidos da comédia de Martins Pena.

\section{LEMBRANÇA DE MARTINS PENA}

Como se sabe, Martins Pena estreou no teatro em 1838 com a comédia $O$ Juiz de Paz na roça, provavelmente escrita aos 18 anos. Em seguida escreveu alguns dramas que são unanimemente repudiados pela crítica, tanto a sua contemporânea quanto a nossa. Seja porque esses dramas não obtiveram boa recepção de público, de crítica ou da "classe", seja porque o próprio autor não se sentiu satisfeito com os resultados alcançados, o fato é que nos seus três anos de maior produtividade (1844 a 1846) só escreveu comédias. Sabe-se também que em 1847 Martins Pena foi para Londres como funcionário do serviço diplomático e morreu tuberculoso em Lisboa, em dezembro de 1848, aos 33 anos de idade. De modo que sua carreira de comediógrafo não foi interrompida apenas pela morte: as exigências do serviço público também concorreram para retirá-lo de nossa cena teatral. É verdade que nosso autor deixou alguns manuscritos interrompidos, tanto de dramas como de comédias, o que permite trabalhar com a hipótese de que o emprego diplomático não teria sido um impedimento definitivo à sua carreira artística. Aliás, o fato de ser um drama o seu último manuscrito incompleto (de 1847) é suficiente para sustentar essa hipótese e, mais que isso, para dar razão às apostas de José de Alencar e Machado de Assis sobre o seu futuro desenvolvimento. Acrescente-se a isso a descoberta de Vilma Arêas: não estava fora dos seus planos a criação de uma ópera (4, p. 94), pois Martins Pena, além de músico e crítico teatral, foi grande apreciador do canto lírico.

Suas comédias também produziram uma espécie de unanimidade da crítica: só a partir de 1844 teriam real mérito teatral e manteriam o mesmo nível literário, o que nos obrigaria a distinguir no conjunto pelo menos três blocos, dos quais só interessariam dois, a saber: o primeiro, constituído pelas três comédias completas escritas entre $1833 \mathrm{e}$ 1842 (O Juiz de Paz na roça, A família e a festa da roça e $O s$ dous ou $O$ Inglês maquinista); e o segundo, contando com as comédias ditas de "real mérito teatral", entre as quais se encontram sucessos duradouros de público, como é o caso de $O$ noviço, As desgraças de uma criança e $O$ Judas em sábado de aleluia. $O$ terceiro bloco reúne as peças apenas esboçadas ou inacabadas, por isso mesmo de interesse menor, ainda que indiquem os rumos que Martins Pena estava tomando. Nossa discrepância em relação a essa unanimidade se expōe na análise que segue.

Num ensaio sobre as Memórias de um sargento de milícias, de Manuel Antonio de Almeida, que constitui um marco histórico na crítica brasileira, como já demonstrou Roberto Schwarz (14), Antonio Candido assim se refere ao nosso comediógrafo: "de 38 a 49 desenvolve-se a atividade de Martins Pena, cuja concepção da vida e da composição literária se aproxima da de Manuel Antonio, com a mesma leveza de mão, o mesmo sentido penetrante dos traços típicos, a mesma suspensão de juízo moral" (3, p. 73). Esta 
observação abre-nos uma pista que ainda permanece inexplorada, mesmo levando em conta o valioso trabalho de Vilma Arêas. Expliquemo-nos: Antonio Candido sugere o exame da obra de Martins Pena à luz da dialética da ordem e da desordem - princípio que norteou a composição das Memórias.

Com base nesse resultado, que pressup̃e a tradição crítica relativa tanto a Manuel Antonio de Almeida quanto a Martins Pena, e levando em conta a incongruência entre seus materiais e as exigências do princípio do drama ou da comédia dramática, mobilizado por nossos críticos e dramaturgos, poderíamos tentar examinar, a exemplo de Antonio Candido, as comédias de Martins Pena segundo critérios exigidos por elas mesmas, trivialidade nada fácil de atender.

Apenas para mencionar algumas das informaçð̃es que os estudos disponíveis sobre Martins Pena nos dispensam de detalhar, enumeremos as seguintes: sua obra prende-se à tradição dos entremezes portugueses, portanto nosso comediógrafo vincula-se à já milenar história da comédia e dos espetáculos populares; suas comédias, por isso mesmo, são predominantemente farsas, embora às vezes se aproximem daquilo que se chamou "alta comédia" na segunda metade do século XIX (questão a ser desenvolvida em outra oportunidade); do ponto de vista sociológico, seus personagens provêm dos estratos intermediários da população (os homens livres numa ordem escravocrata), com eventuais aparições de escravos (ou do tema escravidão); seu principal instrumento de trabalho é o que se convencionou chamar observação de costumes; e, por último, but not least, Martins Pena tratou de colocar em nossos palcos, material e formalmente, traços fundamentais da incipiente sociabilidade brasileira na primeira metade do século passado.

Na medida em que a nossa tradição crítica - por razões sugeridas - estabeleceu a quase total ausência de méritos artísticos (literários) na obra de Martins Pena, e uma vez que, nesse conjunto, apenas Vilma Arêas tenta, por ssim dizer, "salvar" suas comédias desse veredicto, esta abordagem ficará limitada à discussão de pelo menos um aspecto que sua abordagem não relevou. Quando o princípio do drama norteia os julgamentos, a interpretação de algumas comédias fica prejudicada, mas lança luzes preciosas sobre outras.

\section{RAPSÓdIAS CÔMICAS DE MARTINS PENA}

A tentativa de conciliar os elementos formais da comédia com um quadro de costumes no qual se detecta um esboço de trama teria sido uma das causas dos "defeitos" das primeiras comédias do nosso autor. Mas sua segunda peça, $A$ família e a festa da roça, já apresentaria um nítido amadurecimento técnico que se intensificaria nas comédias seguintes. Estas sāo, sumarissimamente indicadas, algumas das principais conclusð̄es das análises de Vilma Arêas naquilo que nos interessa.

Mesmo questionando alguns aspectos da tradição crítica, tais conclusð̃es preservam algumas injustiças históricas cometidas contra o comediógrafo. A mais grave - indicada 
pela própria autora - atribui a Martins Pena uma dose inexplicável de burrice, mesmo para um estreante de 18 anos, e diz respeito ao episódio dos julgamentos ou à importância do juiz na comédia $O$ Juiz de Paz na roça. Vejamos três avaliaçōes mais ou menos recentes sobre essa peça:

Wilson Martins: "na verdade, o juiz de paz é uma figura secundária e lateral, introduzida claramente pelo pitoresco; a intriga principal é a peripécia amorosa entre José e Aninha, filha do lavrador Manuel Joāo" (Apud 4, p. 114).

Barbara Heliodora: "a cen̨a da audiência do juiz de paz é tăo gratuita dramaticamente como preciosa como documentário da época" (5, p. 33).

Vilma Arêas lança mão de um curioso recurso para discordar desses autores, preservando um acordo mais profundo: "como o próprio título indica, o verdadeiro interesse da comédia concentra-se nos julgamentos do juiz, que ocupam a cena central (a mais importante e a mais longa da peça); ora, numa obrinha tão curta (23 cenas), a contradição entre as duas açð̄es determina indecisð̄es quanto ao verdadeiro sujeito da ação (...) a causa da indecisão é que, na peça, herói e sujeito não se confundem; o papel do primeiro é preenchido pelo Juiz, o do segundo, por Aninha" (4, p. 114).

Apenas para localizar o leitor, recapitulemos a pecinha: Aninha, filha de Manuel João, quer casar-se com José que foi "recrutado" para lutar contra os farroupilhas no Rio Grande. Manuel João, pequeno proprietário que sonha com um bom casamento para a filha, é também membro da guarda nacional e por isso subordinado ao Juiz de Paz, de quem recebeu a incumbência de levar o recruta/prisioneiro para a Corte. Como José e Aninha conseguem se casar às escondidas, o rapaz livra-se da convocação e a peça termina com uma festa na casa do juiz. Tal recapitulação, como se vê, dá plena razão aos críticos de Martins Pena, pois nela o juiz é mencionado apenas lateralmente. Barbara Heliodora teria, então, razão ao classificar o episódio do julgamento como dramaticamente gratuito. Pois é mesmo. Mas a explicação para isso é simples: a peça foi aqui "reconstituída" de acordo com a receita dramática, cujo pressuposto fundamental é a presença de um sujeito que realiza uma ação, normalmente chamado protagonista, herói, etc. Vilma Arêas, por sua vez, distingue, na peça, sujeito de herói obedecendo aos preceitos da mesma cartilha. Essa é uma forma de ao mesmo tempo dar e não dar razão aos críticos de Martins Pena, com a vantagem adicional de preservar quase intocado o princípio construtivo do drama.

Vejamos, então, como essa comédia pode ser reconstituída a partir de outro princípio, o épico - que é o dela mesmo -, e, assim, pode ser lida com todas as suas qualidades que até hoje têm passado por defeitos. Vilma Arêas esteve próxima dele quando, entre esses defeitos, mencionou a dispersão espacial, como se se tratasse de um roteiro cinematográfico, assim como a "ligação dramaticamente gratuita" entre a riqueza de informaçāo contextual (dados importantes da história nacional) e a "trama" da peça.

Ao contrário do dramático, o princípio épico não exige sujeitos, heróis, nem muito menos ação dramática (podendo também tê-los e mais de um numa mesma peça) quando o objetivo do dramaturgo é contar uma história ou fragmentos de histórias (flagrantes da vida) no palco. $\mathrm{O}$ que tem sido até hoje tomado por objeto da peça - as aventuras de um 
casal de namorados -, tratado tanto em chave de Comédia Nova quanto de um embrionário princípio dramático; não tem maior interesse que os demais aspectos da peça. Martins Pena estava interessado em miniaturizar a totalidade da situaçāo do país. Como a própria Vilma Arêas indica, seu objetivo é expor criticamente a maneira como funcionam as instituiçð̄es, ou seja, o exercício do arbítrio e da violência desde o âmbito mais geral da "grande" política (a Guerra dos Farrapos) até os detalhes aparentemente mais insignificantes, como a disputa sobre a localização de uma cerca, ou delimitação de propriedades, passando pela indefectível discrepância entre pretensões de pais e filhos sobre o casamento (a família até podia ainda năo ser, conscientemente, a celula mater da sociedade brasileira, mas os proprietários de terras, por menores que fossem, já sabiam muito bem disso). Não sendo a intriga amorosa o fio condutor da peça, é preciso descobrir qual é a idéia que organiza ou preside a disposição dos seus materiais, pois, ao contrário do que sustentaram Sílvio Romero e José Veríssimo, o trabalho de síntese que uma comédia em um ato exige de um autor pressupð̃e muito mais reflexão do que sonha a vã exigência de "idéias e reflexōes filosóficas que sintetizem situaçð̃es" (Cf. 15, p. 1202 passim e 12, p. 29). Idéias que presidem a organização de uma obra de arte não precisam ser filosóficas, já ensinava Hegel a seu tempo. E, dando fé à demonsıração feita por Vilma Arêas de que Martins Pena não era burro nem batizou a sua peça de $O$ Juiz de Paz na roça por descuido ou distração, comecemos pelo julgamento, a partir da cena 9.

Essa cena é uma variante de monólogo na qual somos apresentados ao juiz, que expðe os primeiros aspectos, os mais visíveis de sua condição: tem como auxiliar um escrivão que se atrasou porque deve estar bebendo numa venda próxima; sua honestidade está permanentemente sob suspeita (por exemplo, presos domiciliares podem fugir e depois "vão dizer" que ele comercia com a justiça), e assim por diante. Nesse momento, o juiz recebe exatamente um presente, acompanhado de uma carta na qual o remetente invoca os termos das reformas na Constituição que asseguram o direito de "cada um fazer o que quiser e mesmo de dar presentes". $O$ arremate da cena desmente as preocupaçð̃es iniciais com as aparências de juiz incorruptível: "o certo é que é bom ser juiz de paz cá pela roça. De vez em quando temos nossos presentes de galinhas, bananas, ovos, etc". (11, p. 27)

Com a chegada do escrivão (cena 10) e a entrada dos litigantes, tem início a audiência propriamente dita. O primeiro caso envolve o casal Inácio José e Josefa Joaquina contra o negro Gregório. Este, com uma umbigada, teria agredido a mulher. Por causa disso, o casal quer nada menos que a pena de degredo para o negro, o que de imediato pð̄e em cena o cômico e o absurdo, cuja raiz está no arbítrio e na violência reinantes. É evidentemente cômico que alguém se dirija a um juiz de paz para reclamar de uma hipotética umbigada (in dubita pro réu, já que este repudia a acusação com veemência, alegando que não dá umbigada em bruxas). $\mathrm{O}$ absurdo está na desproporção entre crime e castigo, o que diz muito sobre a nossa propalada "democracia racial" e certamente faz rir desses brancos "justiceiros".

Antes de passar para o veredicto judicial, conviria lembrar o prodígio de síntese exposta nesse litígio. Quem conhece um pouco da cultura negra sabe que uma umbigada 
- movimento coreográfico em diversos tipos de dança - nāo é exatamente uma agressão (depende muito das circunstâncias), podendo, por exemplo, ser expressão pura e simples de interesse sexual, pois simboliza um rito de fecundação que, pelo menos em princípio, e entre iguais, está longe de ser agressivo. Por outro lado, na ótica, do branco, a umbigada em qualquer caso, mas sobretudo se se tratar de manifestação evidente de interesse sexual, é agressiva, independentemente das circunstâncias. E Martins Pena carrega nas cores da petição de Inácio José: "(o negro) teve o atrevimento de dar uma umbigada em sua mulher, na encruzilhada do Pau-Grande, que quase a fez abortar, da qual umbigada fez cair a dita sua mulher de pernas para o ar" (11, p. 28). Josefa Joaquina, por sua vez, deixa evidente a conotação (interesse sexual) da umbigada ao declarar que aquela não teria sido a primeira vez, etc. Está, pois, aberta uma daquelas janelas que a nossa história oficial procurou manter cuidadosamente fechadas: a das relaçð̄es amorosas extracasamento e inter-raciais (como já observou Emília Viotti da Costa (Cf. 6), entre outros estudiosos, em "O mito da democracia racial no país"). Como indicador da leveza de mão de Martins Pena, é de se notar que antes que venham à tona maiores "inconveniências", do ponto de vista de uma certa moral ainda em construção e da qual o juiz já é um legítimo representante, este intervém para interromper o bate-boca esboçado, apaziguar os ânimos e - detalhe importantíssimo - para disciplinar reivindicaçð̄es exorbitantes: "Está bom, senhora, sossegue Sr. Inácio José, deixe-se dessas asneiras, dar embigadas não é crime classificado no código. Sr. Gregório, faça o favor de não dar mais embigadas na senhora; quando não arrumo-lhe com as leis às costas e meto-o na cadeia" $(11$, p. 28). Bem entendido, disciplinar as coisas, aqui, nada mais significa do que deixar patente para todos o alcance ilimitado do arbítrio do juiz. Se para os acusadores deve ficar claro que uma umbigada não é crime, para o acusado, um negro, fica a ameaça de que mesmo assim ele pode acabar na cadeia. $O$ flagrante da contradição entre as declarações do juiz deve ser computado entre os méritos da elaboração artística, mais do que à simples observação de costumes.

Em ensaio de grande interesse, Tania Brandāo procura mostrar o quanto Martins Pena está empenhado na consolidação de uma certa moral (Cf. 12), e a disposição estratégica desta pendência na sessão do julgamento pesa em favor de sua tese. A intervenção do juiz, duplamente disciplinadora - tanto dos excessos vingativos dos brancos quanto das excessivas "impertinências" dos negros -, conta no conjunto da cena para ganhar a disposição do público em seu favor. Trata-se da configuração artística de uma ordem na qual o valor maior é preservar uma estrutura conciliatória em que cada um conheça e respeite os seus limites, sob a égide de um poder, arbitrário sim, mas devidamente calcado no "bom senso".

A pendência, entretanto, ainda não acabou. Nem Martins Pena vai ficar nisso. Quando o juiz ordena que os litigantes se retirem com a tradicional declaração "estão conciliados", o arremate fica por conta de Inácio José que ameaça Gregório com um sugestivo "lá fora me pagarás". Aqui estamos diante da já referida dialética da ordem e da desordem exatamente no lugar (sala de audiências) onde mais se procura escondê-la: para os representantes da ordem basta uma declaração de que o assunto está encerrado; já para os 
"desordeiros", o conflito ainda há de ser resolvido e, como indica Martins Pena, na base da lei do mais forte. Este desarranjo final do episódio, longe de desmentir a tese de Tania Brandāo, parece apontar para um problema que sempre incomodou os paladinos da ordem neste país: por razões que lhes parecem mais ou menos insondáveis, leis, decretos, decisð̄es judiciais nem sempre "pegam". Em outra formulação: o "povo" - lugar da desordem - teima em não se submeter à "ordem" necessária ao bom andamento da "vida civilizada". É isto o que Martins Pena configura aqui, mas esta questāo será trabalhada, a seguir, naquilo que realmente interessa, ou seja, em seu ef eito literário.

A segunda pendência, sobre ser a mais grave, à primeira vista é tratada ainda com maior leveza. Agora a questão é a delimitação da propriedade de Manuel André, cuja metade é reivindicada pelo vizinho. Deixando de lado os aspectos desfrutavelmente cômicos das eventuais "razð̃es do vizinho", acompanhemos apenas o nó desta questão. $O$ interessado solicita a presença do juiz nos trabalhos de demarcação, o que lhe parece ser um meio de garantir seus direitos. E para contar com o seu empenho, promete-lhe uma propina. Mas o juiz, sem se mostrar of endido sequer para fins de credibilidade, declara que não terá tempo para cuidar desse caso por andar muito ocupado com sua própria plantação. Diante do protesto de Manuel André, o juiz ameaça-o com a cadeia. Quando o litigante se defende brandindo seus direitos constitucionais, cai a máscara tão cuidadosamente delineada do juiz equânime:

“Juiz - A Constituição! ... Está bem! ... Eu, o Juiz de paz, hei por bem derrogar a Constituição! Sr. Escrivão, tome termo que a Constituição está derrogada, e mande-me prender este homem.

Manuel André - Isto é uma injustiça!

Juiz - Ainda fala? Suspendo-lhe as garantias...

Manuel André - É desaforo...

Juiz, levantando-se - Brejeiro!... (Manuel André corre; o juiz vai atrás) Pega ... Pega ... Lá se foi ... Que o leve o diabo." (11, p. 28).

Este diálogo rápido, que parece visar apenas ao efeito cênico (sobretudo quando a peça é lida à luz de critérios dramáticos), pode ser considerado como um retrato em branco e preto do país - objeto do comediógrafo: dispōe de uma constituição que assegura aos cidadãos determinados direitos, sobretudo aos proprietários. Mas esses direitos tanto podem ser usurpados, porque os encarregados de sua estrita observância "têm mais o que fazer", quanto simplesmente derrogados, num evidente abuso da autoridade (uma das formas mais execráveis de violência aos olhos da boa moral burguesa), pela simples razão de que o "agente da lei", flagrado no abuso da autoridade por um cidadão que conhece os seus propalados direitos, inverte a situação e transforma-se de agressor em vítima. Trata-se, enfim, do tristemente famoso e, pior ainda, perfeitamente atual "desacato à autoridade". Mas, ao contrário do que acontece hoje, sobretudo devido à truculência dos "homens da lei" e ao estágio muito mais acirrado da desconfiança em relação aos desclassificados, o incidente ocorrido entre Manuel André e o juiz não resultou na prisāo do "brejeiro", que conseguiu fugir. Quanto à demarcação de suas terras, 
assim como ocorreu no primeiro litígio, trata-se de problema a ser resolvido por ele mesmo. Provavelmente ao arrepio da lei, ou segundo a lei do mais forte. Martins Pena deixa a questão em aberto, o que é um feito literário, como veremos.

Duas questōes, uma de ordem formal, outra temática, já estāo claramente apontadas nestes dois pequenos episódios. Do ponto de vista formal, as duas pendências explicitam a natureza épica do julgamento (não foi por acaso que uma das primeiras formas do moderno teatro épico a reaparecer no século XX tenha sido justamente o que se convencionou chamar "teatro tribunal"). Contrariamente ao que depois o drama passou a exigir, a comédia "popular" e sobretudo a farsa estāo permanentemente apontando para fora de si. Ou, para dizer a mesma coisa, elas contextualizam-se remetendo sempre para um antes e um depois. Por isso, a dispersão, e não apenas a espacial, que no drama é um pecado mortal, pois destrói a sua unidade, na comédia - e na de Martins Pena -, longe de ser um defeito é tão simplesmente um recurso necessário à forma. É assim que no Juiz os acontecimentos que deram lugar às pendências são sumariados ou reconstituídos numa palavra, narrados - através do recurso temático da leitura da petição, habitual nos tribunais. À reconstituição dos fatos segue-se o julgamento e, aqui, se não uma novidade introduzida por Martins Pena, temos pelo menos a formalização de um traço fundamental na experiência brasileira: o encerramento formal da questão pelo juiz em nenhum dos casos significou a solução do problema, pois os nós permaneceram. Apontando para um depois, para fora da peça, para a vida real, como se costuma dizer, nosso autor ao mesmo tempo permanece no interior de uma velha tradição e configura um traço da vida brasileira - o formalismo das instituiçð̃es, que não interfere na vida dos desfavorecidos, a não ser para piorá-la, desmentindo as suas expectativas. Por outro lado, pode-se dizer que vêm de longe as observaçð̃es literárias que deram base empírica para as teorias do "Brasil real $x$ Brasil oficial".

Ligada intimamente a esta questão está a novamente atualizada temática da cidadania, que já deixamos esboçada acima. De acordo com os materiais arranjados por Martins Pena, é possível arriscar o palpite de que, para ele, tal idéia está completamente descartada numa situação em que até mesmo o direito mais sagrado até numa "monarquia constitucional" - 0 de propriedade - depende dos bons ou maus bofes de um agente do poder imperial (ou constitucional?). Ora, não havendo a base sobre a qual repousa a ideologia do "indivíduo autônomo e livre, sob o império da lei", ou o cidadão, com seus direitos reconhecidos e respeitados, um dramaturgo conseqüente não se arriscaria a escrever dramas (risco do qual, como sabemos, Martins Pena não escapou). Mas, pelo menos nesta primeira peça, ao dar o devido destaque ao juiz de paz da roça (a forma "legal" de "interiorização do desenvolvimento"), ele escapou do risco de participar mais ativamente de nossa comédia ideológica, justamente porque a surpreendeu desmascarando alguns de seus aspectos.

O litígio seguinte mostra uma outra faceta do comediógrafo, assim como um novo aspecto das práticas "judiciosas" do seu "herói". Será experimentado um milenar recurso que acabou se tornando dos mais fecundos na nossa tradição teatral - a paródia - e chegou 
a render alguns bons achados na própria obra de Martins Pena. É o caso de $O$ diletante (paródia muito divertida da Norma, ópera então popularíssima) e Os ciúmes de um pedestre (paródia do Otelo, um dos cavalos de batalha do nosso João Caetano, aqui popularizada na concepsão francesa, de Ducis).

Neste caso, Martins Pena também tem um pé na própria tradição da comédia, melhor dizendo, da farsa, em que os mais variados litígios são pretexto para se ridicularizarem advogados, juízes e poderosos de plantão (pensemos na mais antiga farsa conhecida na França, a do Mestre Pathelin, do século XV). Mas a solução para o litígio aqui apresentado é uma paródia de episódio bíblico. Trata-se do incidente entre Tomás e João Sampaio, no qual o primeiro alega que um leitão, propriedade do segundo, é seu porque furou a sua cerca e alimentou-se em sua horta. Em vista disso (se o leitão está vivo é porque comeu seus legumes), Tomás considera-se no direito de reivindicar a propriedade do animal, com o que Joāo Sampaio, evidentemente, não concorda. Os dois agarram-se ao leitão, puxando-o cada um para seu lado, quando tem lugar a "salomônica" intervenção do juiz:

"Juiz, levantando-se - Larguem o pobre animal, não o matem!

Tomás - Deixe-me, senhor!

Juiz - Sr. Escrivão, chame o meirinho. (Os dois apartam-se). Espere, Sr. Escrivão, não é preciso. (Assenta-se). Meus senhores, só ve jo um modo de conciliar essa contenda, que é darem os senhores esse leitão a alguma pessoa. Não digo com isso que mo dêem." $(11$, p. 29).

Não é preciso dizer que ambos concordam imediatamente com a insinuação. E o juiz, de quebra, ainda consegue ser presenteado (após ter feito a devida sugestão) com algumas ervilhas por Tomás. Afinal, tratava-se de fazer "justiça" e este também teria que ceder alguma coisa. Desta vez o juiz consegue conciliar os contendores fazendo paródia explícita do famoso julgamento de Salomão, mas com a sabedoria própria de pequeno e interesseiro magistrado. $\mathrm{O}$ cômico da situação está tanto na reação preocupada com o "pobre animal", que remete a Salomão, quanto na preterição ostensiva (não digo que mo dêem).

Se o juiz conseguiu conciliar estes contendores, docemente constrangido a apropriarse do pomo da discórdia, nem por isso as contas ficaram acertadas, pelo menos para Tomás. Novamente, através de técnicas épicas, temos a remissão a acontecimentos passados e a permanência da causa do problema. Numa nova reivindicação exorbitante e por isso mesmo cômica, Tomás pede ao juiz que cite a Assembléia Provincial "para mandar fazer cercado de espinhos em todas as hortas":

"Juiz - Isto é impossível! A Assembléia Provincial não pode ocupar-se com essas insignificâncias.

Tomás - Insignificância, bem! Mas os votos que Vossa Senhoria pediu-me para aqueles sujeitos não eram insignificância. Então me prometeu mundos e fundos.

Juiz - Está bom, veremos o que poderei fazer" (11, p. 29). 
Como se pode ver, são vários os pesos e medidas. Quando se trata de cidadãos propriamente ditos - os que, além de proprietários, podem votar -, o juiz promete tratar do caso. Tão importante quanto a diferença de tratamento dos personagens é a identidade do procedimento do dramaturgo, a insistir na seguinte caracterização do juiz: se sua presença não resolve os problemas dos cidadãos (qualquer que seja o seu estrato econômico), a possibilidade de locupletar-se parece ser a razão de sua existência.

Desenvolvendo em outro sentido a paródia da justiça salomônica, Martins Pena encerra a audiência do dia com uma disputa que, além de introduzir mais uma nota relativa a costumes tão generalizados quanto programaticamente esquecidos pelos arquitetos da nossa história em versão idílica, permite-lhe realizar um bem sucedido jogo de construçð̄es com duplo sentido, graças às características da língua portuguesa. Por se tratar de jogo de palavras, vale a pena reproduzir tanto a petição quanto o diálogo que a segue:

"Escrivão, lendo - Diz Francisco Antônio, natural de Portugal, porém brasileiro, que tendo ele casado com Rosa de Jesus, trouxe esta por dote uma égua. 'Ora, acontecendo ter a égua de minha mulher um filho, o meu vizinho José da Silva diz que é dele, só porque o dito filho da égua de minha mulher saiu malhado como o seu cavalo. Ora, como os filhos pertencem às mães, e a prova disso é que a minha escrava Maria tem um filho que é meu, peço a V. Sa. mande o dito meu vizinho entregar-me o filho da égua que é de minha mulher'.

Juiz - É verdade que o senhor tem o filho da égua preso?

José da Silva - É verdade; porém o filho me pertence, pois é meu, que é do cavalo.

Juiz - Terá a bondade de entregar o filho a seu dono, pois que é aqui da mulher do senhor.

José da Silva - Mas, Sr. Juiz...

Juiz - Nem mais nem meio mais, entregue o filho, senão, cadeia.

José da Silva - Eu vou queixar-me ao Presidente.

Juiz - Pois vá, que eu tomarei a apelação.

José da Silva - E eu embargo.

Juiz - Embargue ou não embargue, embargue com trezentos mil diabos, e eu não concederei revista no auto do processo!

José da Silva - Eu lhe mostrarei, deixe estar.

Juiz - Sr. Escrivão, não dê anistia a este rebelde, e mande-o agarrar para soldado.

José da Silva, com humildade - Vossa Senhoria não se arrenegue! Eu entregarei o pequira". (11, p. 29).

Não há de ter passado despercebida a rapidez com que essa pendência é resolvida, nada casualmente em favor do português. Mas não é este o ponto importante aqui, como não é a "imparcialidade" com que o juiz interpreta o argumento da paternidade. 
É um lugar comum da crítica a exigência de que poetas tenham bom conhecimento da língua. Já com relação a comediógrafos não se tem registros tão freqüentes dessa exigência. Este episódio de Martins Pena mostra tanto o seu perfeito domínio da língua quanto o agudo golpe de vista em relação ao ef eito cômico procurado no nível da ambigüidade: ao ceder às ameaças do juiz, por exemplo, José da Silva diz que vai entregar o pequira - um adjetivo que tem o duplo sentido criado pelo requerimento pois, a partir de seu significado original (do tupi, picuíra, pykyra = pequeno), usado para animais, significa pequeno e, para pessoas, sujeito insignificante. Convenhamos que para um comediógrafo a quem têm sido tradicionalmente atribuídas qualidades negativas tais como observação trivial ou superficial dos costumes, falta de talento, poucos recursos (os mais desgastados pela comédia), talento apenas para fotografar instantaneamente o seu meio, de traço e linguagem ingênuos e sem composição, e assim por diante, um achado como o referido, já na sua peça de estréia, ao menos dá direito ao benefício da suspensão do juízo.

É bem verdade que o conjunto da tradição cômica popular tem sido vítima dos mesmos preconceitos, tidos como verdade igualmente válida para as classes dominadas. Os mais comuns são a burrice, ou inteligência limitada, a grosseria ou grossura, a rusticidade ou falta de refinamento, o mau gosto, a vulgaridade, a incultura, a falta de modos ou de educação. Todos esses "conceitos" são sinônimos. Claro que tanto apoiados em "evidências empíricas" quanto recorrentes, dado o seu significado único: próprio de tudo o que está excluído das elites, já que o seu contránio, salvo as providenciais exceçð̃es que "confirmam a regra", só pode ser pensado a respeito dos membros da elite que os cunhou, ou seja, há uma espécie de evidência que dispensa demonstração de que apenas as elites são cultivadas, delicadas, têm fino trato, bom gosto, são inteligentes, têm agilidade de pensamento, etc., etc. Daí que por uma operação simples de raciocínio tenha sido vedada a comediógrafos provenientes da malta a atribuição de qualidades tais como poder de síntese, capacidade de análise profunda de situaçð̃es, agilidade no trato com a língua (privilégio de certos poetas) e tantas outras que entretanto podem ser facilmente observadas já no jovem Martins Pena. E o que prevaleceu foi a idéia de que nosso autor "não fez sequer literatura".

Não sendo o caso de enveredar agora pela história do exame crítico dessas categorias classistas, nem muito menos o de repisar as mais que problemáticas trilhas do populismo teórico, a intenção aqui é apenas evidenciar um elemento decisivo em qualquer obra de caráter cômico: o trabalho intelectual (e agilidade de pensamento) que pressupōe, por ser sobretudo síntese. Uma capacidade que não depende da origem social do artista, por mais que as classes dominantes estabeleçam critérios classistas para a sua medida.

Mas voltando à pendência em que nos encontrávamos, a petição de Francisco Antônio, sempre no território do duplo sentido alcançado pela utilização ao mesmo tempo correta e viciosa da construção sintática, contém ainda uma informação adicional sobre costumes nacionais, digamos que menos recomendáveis para certos padrões de moral e hiprocrisia institucionalizada. Trata-se do argumento da paternidade, aparentemente irrefutável: "os filhos pertencem às mães e a prova disso é que Maria tem 
um filho que é meu" - com o detalhe importante de ser Maria uma escrava. Lido à luz das circunstâncias, $o$ argumento se destrói, pois se os filhos das escravas pertencem aos senhores, então não pertencem a suas mães. Detalhe artisticamente da maior relevância quando se sabe que mesmo depois de aprovada a Lei do Ventre Livre muitos senhores continuaram a apropriar-se de filhos de escravas. Mas em sua ambigüidade deliberada, 0 argumento aponta ainda para o outro lado das nossas práticas inter-raciais, a saber, para a possibilidade de Francisco Antonio ser mesmo o pai dessa criança, podendo declará-lo sem o menor constrangimento. Independentemente do seu conteúdo, este tipo de ambigüidade é um recurso tão antigo da comédia e da farsa quanto a repressão a essas formas ou a seus "exageros", todos "vulgares" e de "mau gosto", et pour cause. A história desse combate, sobretudo entre os séculos XV e XVIII, registra uma quantidade inacreditável de prisð̄es, multas, exílios, perseguiçðes, tanto por parte das igrejas quanto dos demais poderes constituídos. Basta lembrar o caso da commedia dell'arte e seus parentes espalhados por toda a Europa, num turismo teatral um tanto quanto forçado.

No Brasil, a história não mudou muito, devidamente guardadas as proporçð̃es e as diferenças de fuso horário. Como em outras praças, métodos variados de domesticação dos maus modos dos comediantes e comediógrafos foram utilizados. Desde o emprego da pura e simples força bruta, até a "leal" disputa da preferência do público no mercado, passando, através dos mecanismos do favor, pela cooptação dos melhores encontrados na fileiras "inimigas". O próprio Martins Pena conheceu todas as táticas: fazia grande sucesso de público, foi violentamente censurado pelo Conservatório Dramático e, nada excepcionalmente, em se tratando de artista que "deu certo" no Brasil, também ele foi censor do mesmo Conservatório Dramático.

Num tropeço típico de iniciantes, para encerrar sua audiência Martins Pena ainda cria uma nova cena, esta sim gratuita, e não do ponto de vista dramático, mas segundo qualquer critério: trata-se de uma óbvia pretensão de "fecho de ouro" que prima pela redundância, no qual uma mulher vem trazer ao juiz mais um presente. Ora, o juiz já havia mostrado à saciedade o seu grau de corruptibilidade, a ponto de induzir a iniciativa de suas vítimas. $\mathrm{Na}$ comédia, forma em que a rapidez tem peso máximo, a insistência sobre qualquer aspecto caracteriza def eito flagrante. Neste caso, tanto é expressão da imaturidade do autor quanto da relação que ele estabelece com seu público, pois, ao reiterar uma característica de personagem suficientemente estabelecida, inevitavelmente põe um pé na canoa do paternalismo. Eis nosso comediógrafo inconscientemente às voltas com o mesmo problema que examina em seu personagem e saindo-se muito mal.

Antes de passar para as considerações finais a respeito dessa audiência "dramaticamente gratuita", um tema a ser desenvolvido em outra oportunidade pode ficar esboçado a partir do exposto: ao inspirar-se numa situação jurídica, na qual personagens sem qualquer relação dramática entre si desfilam seus problemas diante do público, Martins Pena não somente inaugurou a "comédia nacional", como quer a nossa tradição crítica, mas ainda adaptou para as reduzidas dimensões do palco a forma épica do desfile (ou da procissão). Quanto à longevidade dessa forma, nossa indústria cultural apresenta, 
ainda hoje e com muito sucesso popular, uma versão degradada nos programas televisivos "Praça Brasil"e "A praça é nossa", para dar apenas um exemplo, pois se trata da mesma concepção em emissoras diferentes. Um desenvolvimento real, e por isso bem mais interessante do ponto de vista da estética, são os desfiles de escola de samba no camaval.

Deixamos para examinar agora a ameaça feita pelo juiz a José da Silva - mandá-lo para a Guerra dos Farrapos -, que tão rapidamente fez o recalcitrante abandonar a sua postura, tendo em vista a sua função temática de religar o episódio central da audiência ao restante da peça. A referência à Guerra dos Farrapos tem função recapitulativa, pois remete o espectador ao motivo dos problemas dos namorados Aninha e José. Este está preso e corre o risco de ser enviado ao Rio Grande. Manuel João, o pai da moça, é responsável pela escolta ao recruta à corte.

Como o espectador também há de estar lembrado, no início da cena 9 , o juiz deixou claro que não queria ter o prisioneiro sob seus cuidados durante a noite, etc. Esta sua disposição para evitar aborrecimentos e maledicência "infundada" a seu respeito vai facilitar a vida dos jovens. Conduzido à casa de Manuel João, por ordem do juiz, José consegue, com a ajuda de Aninha, escapar dessa prisão domiciliar e fugir com a namorada. Os dois de casam às escondidas numa igreja próxima e às autoridades civis (o pai e o juiz) só resta abençoar a união (que livra José do recrutamente forçado), providenciar uma vida digna para o casal e, claro, festejar o casamento, que ninguém é de ferro.

Tudo, portanto, muito leve e inocente. Mas para além dessa inocência e leveza deparamo-nos com o peso da violência reinante no país. Uma violência a que nada escapa, nem os sonhos de vida modesta mas despreocupada na corte, acalentados pelos jovens e pragmaticamente contidos pelo paternalismo dos mais velhos.

As outras peças do jovem Martins Pena - Um sertanejo na corte e A familia e a festa na roça -, segundo ficou estabelecido, mostrariam já indícios do que passa por amadurecimento técnico do comediógrafo. $O$ que ainda não se sabe é o preço desse amadurecimento. Após a apresentação desta última (1840), Martins Pena dedica-se, sem sucesso, às tentativas dramáticas. Volta, então, ao terreno da comédia já em $1842 \mathrm{e}$, à ribalta, em 1844, com $O$ Judas em sábado de Aleluia e Os irmãos das almas. A partir desta data, o comediógrafo exibiria pleno conhecimento de seu ofício.

Uma vez que o critério para definir "amadurecimento técnico" envolve a idéia de adoção do drama ou, o que dá no mesmo, descoberta da comédia dramática, algumas características começam a ser aplaudidas em Martins Pena. Destaquemos as duas mais importantes: desenvolvimento cuidadoso da trama, ou do enredo e dos conflitos (sempre em torno de encontros e desencontros amorosos, é claro), e concentração no espaço. Realmente, a partir de $O$ s dous ou $O$ inglês maquinista, de 1842, todas as suas comédias passam a ter como espaço cênico sempre uma sala de visitas, com uma exceção perfeitamente justificada, $O$ Namorador ou Noite de Säo Joäo. 
Posto o critério, fica naturalmente computado entre os defeitos mais insistentes do comediógrafo o hábito de reconstituir, através dos diálogos dos personagens, episódios inteiros ocorridos fora da cena, justamente porque são narrados e, portanto, pouco "teatrais". Não é preciso dizer que esse critério acaba desqualificando até mesmo materiais que concorrem para a caracterização social e psicológica dos personagens - aliás, uma "falha" habitualmente observada em Martins Pena é a falta de "aprofundamento psicológico". A equação, no entanto, é clara: desqualificados por "não dramáticos" os seus recursos para o desenho dos personagens, pode-se a seguir cobrar exatamente a falta desse desenho. É o caso, por exemplo, do seguinte episódio "dramaticamente irrelevante" na peça $O s$ irmãos das almas, que certos diretores contemporâneos não hesitariam em eliminar de uma encenação pautada pelo "teatral":

"Entra Mariana, apoiada nos braços de Eufrásia e de Sousa.

Mariana - Ai, quase morri... Tira-me esta mantilha (Luíza tira-lhe a mantilha). Ai (Senta-se). Muito obrigada, compadre.

Sousa - Não há de quê, comadre.

Eufrásia - Acha-se melhor, minha mãe?

Mariana - Um pouco. Se o compadre não estivesse lá à porta da igreja para tirar-me do aperto, eu morria, certamente.

Sousa - Aquilo é um desaforo!

Mariana - É assim, é. Ajuntam-se esses brejeiros nos corredores das catacumbas para apertarem as velhas e darem beliscðes nas moças.

Sousa - E nos rasgarem as opas e darem caçoletas.

Eufrásia - É uma indecência!

Mariana - Espremeram-me de tal modo, que ia botando a alma pela boca a fora.

Eufrásia - E a mim deram um beliscão que quase arrancaram a carne.

Mariana - É insuportável!

Sousa - Principalmente, comadre, em S. Francisco de Paula.

Mariana - Estão horas inteiras num vaivém, só para fazerem patifarias.

Euf rásia - A polícia não vê isso?

Mariana - Ai, estou que não posso, compadre, dê-me licença que vou-me deitar um pouco" (11, p. 119).

Se um Sílvio Romero certamente saudaria essa página pela quantidade de informaçð̃es sobre costumes populares daqueles idos, nenhum crítico aí encontraria méritos literários. Mas estão presentes tanto aquelas qualidades já apontadas (agilidade, poder de síntese, noção aguda de tempo), quanto os problemas que a "maturidade técnica" impôs ao conteúdo de Martins Pena. A zoeira do cemitério em dia de Finados realmente ficaria mais "teatral" se apresentada no momento em que as estrepolias iam acontecendo. Mas para além dos limites de elenco (nenhuma companhia da época, a não ser as líricas, teria condições financeiras para reunir o número de atores e comparsas necessário para 
configurar com um mínimo de realismo cênico a multidão que acorre aos cemitérios nesse dia e, conseqüentemente, as situaçð̃es constrangedoras a que se referem as personagens), se Martins Pena optasse pela solução "teatral", novamente precisaria lançar mão dos recursos que já abandonara, tais como dispersão espacial e sequiência de quadros. Isso para não falar nas conseqüências que tal opção teria em termos de prejuízos para o conteúdo em questão, na medida em que poderia diluir justamente o seu conflito dramático. .

A idéia de Martins Pena, entretanto, é mais séria do que simplesmente mencionar episódios pitorescos ocorridos com suas personagens, ou chamar a atenção para aspectos da vida popular fluminense; como ele quer tanto mostrar as pretensð̃es de ascensão social exteriorizáveis em critérios de educação e comportamento elegante, quanto dar aos expectadores motivos para rir das atribulaçð̃es das personagens negativas da peça (duas mulheres que tiranizam seu pobre herói, Euf rásia, a esposa, e Mariana, a sogra), é preciso examinar o peso específico do episódio em relação ao assunto, bem como os recursos disponíveis para dele tratar adequadamente. E parece que neste caso estamos diante de um exemplar daquilo que só começará a fazer sentido quando se desenvolver o drama conversação - um dos capítulos da crise da forma do drama - sobretudo na Inglaterra, e na França, já neste século.

O que temos nesta breve cena-conversação é a reconstituição de uma experiência desagradável para os personagens que foram ao cemitério homenagear os mortos em Finados. Uma ação duramente castigada por "brejeiros" que se aproveitam de situaçð̃es desse tipo para importunar os incautos, sobretudo mulheres. Na qualidade de vítimas da situação, portanto pacientes e não agentes do ocorrido, que é o que interessa, inclusive do ponto de vista dramático, mas ao mesmo tempo sendo o foco a partir do qual os incidentes, além de cômicos, passam a ser relevantes, tais personagens têm de ser os portadores (arautos) das ocorrências - seus narradores, enfim. Se não houvesse outras razð̄es para propor outro tipo de leitura, alternativo às correntes sobre a obra de Martins Pena, tal proposta já se justificaria pelo que acaba de ser exposto. Em poucas palavras: mesmo nos momentos em que nosso comediógrafo conseguiu impor ao seu conteúdo o princípio do drama, por mais desajeitada que tenha sido essa imposição, aqueles aspectos que normalmente são apresentados como "falhas técnicas" podem, aliás, devem ser vistos como recursos de que ele se utiliza tendo em vista tanto a heterogeneidade entre conteúdo disponível e forma importada quanto as limitaçðes dessa mesma forma.

Estamos, com isso, dando razão a José de Alencar e Machado de Assis: é bem provável que se não morresse tão cedo Martins Pena acabaria escrevendo excelentes exemplares de alta comédia. Para isso seria necessário que, entre outras providências, mudasse o foco do seu olhar das camadas pobres da população carioca para a aristocracia e a corte, já que ao morrer parecia estar de posse dos instrumentos adequados para configurar o que ainda não vira muito bem. O que não dá para saber é se essa "obra de maturidade" manteria o mesmo vigor crítico das que deixou ou se apenas alimentaria a nossa vasta comédia ideológica com mais alguns capítulos. 
COSTA, I. C. - Martins Pena's classless comedy. Trans/Form/Ação, São Paulo, 12: $1-22,1989$.

ABSTRACT: After pointing out the ideologic character of basic concepts usually employed in dramatic literature analysis, this study tries to show how we can see farther when free from their limitations. Once noted the classist basis of theatre theories in Brazil, ideological fight arises as an useful spotlight to illuminate the regularly shadowed faces of Martins Pena's comedies

KEY-WORDS: Modern theatre; drama, comedy of manners; dramatic comedy; high comedy; farce; dramatic literature; epic theatre.

\section{REFERÊNCIAS BIBLIOGRÁFICAS}

1. AgUiAR, F. A comédia nacional no teatro de José de Alencar. São Paulo, Ática, 1984.

2. ALENCAR, J. de. A comédia brasileira. In: — Obra Completa. Rio, Aguilar, 1960. v. 4.

3. ANTONIO CANDIDO. Dialética da malandragem. Revista do IEB, São Paulo, 8, 1970.

4. ARÊAS, V. Na tapera de Santa Cruz. São Paulo, Martins Fontes, 1987.

5. BARBARA HELIODORA. A evolução de Martins Pena. Dionysos, Rio de Janeiro, 13, 1966.

6. COSTA, E. V. da. Da monarquia à república; momentos decisivos. 4 ed. São Paulo, Brasiliense, 1987.

7. Damasceno, D, ed. Comédias de Martins Pena. Rio de Janeiro, Ed. Ouro, s.d. (Introdução).

8. LUKÁCS, G. Teoria do romance. Lisboa, Presença, s.d.

9. MACHADO DE ASSIS, J. M. Literatura brasileira. Instinto de Nacionalidade. In: . Obras Completas. Rio de Janeiro, Jackson, 1959. v. 29.

10. MACHADO DE ASSIS, J. M. O teatro de José de Alencar. In: - Obras Completas. Rio de Janeiro, Jackson, 1959. v. 30.

11. MARTINS PENA, L. C. Comédias de Martins Pena. Rio de Janeiro, Ed. Ouro, s.d.

12. NEVES, T. B. P. Martins Pena e a questão do teatro nacional. Rio de janeiro, SNT, 1979. (Monografias, 1977).

13. RODRIGUES, J. As idéias e as palavras; notas sobre a identidade cultural de Luís Carlos Martins Pena. Rio de Janeiro, SNT, 1979. (Monografias, 1977).

14. SCHWARZ, R. Pressupostos, salvo engano, de "Dialética da malandragem". In: - Que horas são? São Paulo, Cia. das Letras, 1987.

15. VERÍSSIMO, J. Martins Pena e o teatro brasileiro. In: Estudos de literatura brasileira, 1aㅗ série. Belo Horizonte/São Paulo, Itatiaia/Edusp, 1976. 